\section{Journal of Anatolian Environmental and Animal Sciences \\ (Anadolu Çevre ve Hayvancılık Bilimleri Dergisi) \\ Doi: https://doi.org/10.35229/jaes.586428}

\title{
Demlenmiş Çay Atığı ve Evsel Yemek Atıkları İle Beslenen Kırmızı Kaliforniya Solucanından Elde Edilen Katı Solucan Gübresindeki Bazı Besin Elementlerinin Belirlenmesi
}

\author{
Turan YÜKSEK ${ }^{*} \quad$ Vagif ATAMOV $^{2} \quad$ Kevser TÜRÜT $^{2}$ \\ ${ }^{1}$ Recep Tayyip Erdoğan Üniversitesi, Güzel Sanatlar, Tasarım ve Mimarllk Fakültesi, Peyzaj Mimarlı̆̆ Bölümü, 53100, Rize. \\ ${ }^{2}$ Recep Tayyip Erdoğan Üniversitesi, Fen Edebiyat Fakültesi, Biyoloji Bölümü, 53100, Rize \\ *E: https://orcid.org/0000-0003-2964-1760, @: https://orcid.org/0000-0002-6718-7979, ®: https://orcid.org/0000-0002-0264-1763
}

Received date: 03.07.2019

Accepted date: 19.08 .2019

Atıf yapmak için: Yüksek, T., Atamov. V. \& Türüt, K. (2019). Demlenmiş Çay Atığı ve Evsel Yemek Atıkları İle Beslenen Kırmızı Kaliforniya Solucanından Elde Edilen Katı Solucan Gübresindeki Bazı Besin Elementlerinin Belirlenmesi. Anadolu Çev. ve Hay. Dergisi, 4(2), $263-271$.

How to cite: Yüksek, T., Atamov. V. \& Türüt, K. (2019). Determination of Some Nutrient Elements in Solid Vermicompost Obtained From Red California Worm Feeding With Brewed Tea Waste and Domestic Food Waste. Anatolian Env. and Anim. Sciences, 4(2), 263-271.

Öz: Evsel kökenli yemek atıkların değişik yöntemlerle geri kazanılması bir yandan çevrenin korunması; diğer yandan ulusal ekonomiler için çok büyük bir öneme sahiptir. Bu çalışmada, demlenmiş çay atığı ve evsel yemek atıkları ile beslemenin Kırmızı Kaliforniya solucanından elde edilen katı solucan gübresindeki bazı besin elementlerine etkisi araştırılmıştır. Bu amaçla, Recep Tayyip Erdoğan Üniversitesi toprak laboratuvarında altı farklı besi ortamında rastgele yönteme göre üç tekrarlı deneme deseni kurulmuştur. Denemelerin her birine başlangıç ağırlıkları belirlenen besi ortamları ve bu besi ortamlarının içine ağırlıkları tespit edilen 30'ar adet solucan eklenmiştir. 1 ay arayla deneme kaplarındaki solucanlar sayılmış, ağırlıkları belirlendikten sonra tekrar deneme kaplarına bırakılmıştır. Sekiz haftadan (besi yemleri tamamen gübreye dönüştükten sonra) sonra solucan gübreleri alınmış ve hava kurusu hale getirildikten sonra analiz edilmiştir. Araştırma sonucunda en yüksek solucan sayısı ve ağırlığına \%50 demlenmiş çay atığ 1 \% 50 inek gübresi besi ortamı karışımından elde edilen solucan gübresinde rastlanmıştır. Yemek atıklarının \%50'den daha fazla olduğu B, C ve F besi ortamlarında solucanların öldüğü belirlenmiştir.

Besi ortamlarından elde edilen solucan gübresindeki en yüksek azot değerine (\% 2,16) \%100 demlenmiş çay atı̆̆ından elde edilen solucan gübresinde, en yüksek fosfor, potasyum, kalsiyum, çinko, bakır, demir, magnezyum ve pH değerlerine \%50 demlenmiş çay atığ1 $+\% 50$ inek gübresinden elde edilen solucan gübresinde, en yüksek mangan değerine $\% 40$ demlenmiş çay atığ $1+\% 40$ yemek atığ $1+\% 20$ inek gübresinden elde edilen solucan gübresinde rastlanmıştır. Saf haldeki yemek atıklarının ayrı bir fermantasyon sürecinden geçirilmesi ve diğer organik kökenli atıklarla karışım halinde kullanılması solucanların yaşamasına ve daha yüksek kalitede organik solucan gübresi üretilmesine katkı sağlayabilir. Bu nedenle, vermicompostlaşmada kullanılacak atıkların kompostlaştırılma yöntemi, kompostlaştırılma süresi ve ilgili büyüme ortamlarında solucan beslenmesi ve vermicompostlaşma ile alakalı yeni araştırmalara ihtiyaç vardır.

Anahtar sözcükler: Besin elementleri, demlenmiș çay atığı, evsel yemek atığı, Kaliforniya solucanı, vermikompost.

\section{Determination of Some Nutrient Elements in Solid Vermicompost Obtained From Red California Worm Feeding With Brewed Tea Waste and Domestic Food Waste}

\begin{abstract}
Recycling of domestic food waste by various methods, not only protecting the environment but also great importance for national economies. In this study, the effect of feeding materials (e.g.brewed tea waste and domestic food waste, and their mixtures with cow dung) on the number and weight of Red California Worm and some nutrient elements of vermicompost were investigated. This study is the first research to obtain solid vermicompost with Red California Worm from domestic food waste in Turkey. In this study, three repeating trial designs were applied in six different feeding materials according to random method. For this purpose, initial weights of the feeding materials assigned and 30 Eisenia fetida were added in the each of the experiments. Worms number and weight were determined once every 4 weeks after then returned to the experimental box. After eight weeks, eartworms were removed from vermicompost and later vermicompost air dried for laboratory analyses. As a result of study, The highest number and the heaviest weight of worms were found in the feeding material of brewed tea waste $50 \%+$ cow dung $50 \%$. It was determined that worms died in B, C and F feeding materials where food waste was more than $50 \%$. The highest $\mathrm{N}$ value $(2,16 \%)$ was determined in the vermicompost which formed brewed tea waste $(100 \%)$ feeding material, The highest $\mathrm{P}, \mathrm{K}, \mathrm{Ca}, \mathrm{Zn}, \mathrm{Cu}, \mathrm{Fe}, \mathrm{Mg}$ values and $\mathrm{pH}$ were determined in the vermicompost which formed brewed tea waste $(50 \%)+$ cow dung $(50 \%)$ feeding material, and the highest Mn value was determined in the vermicompost which formed brewed tea waste $(40 \%)+$ food waste $(40 \%)+$ cow dung $(20 \%)$ feeding material, respectively. The effect of composition time of organic waste materials as different media should be considered on the weight and number of worms and certain nutrient elements of vermicompost. Therefore, there is need to new research for composting method, composting time and growth media.
\end{abstract}




\section{GíRiş}

Sanayileşme ve teknolojik gelişmelerin beraberinde getirdiği hızlı kentleşme ve nüfus artı̧̧ı bütün dünyadaki insan aktiviteleri çevre üzerindeki baskıyı daha da artırmaktadır. Bu süreçte sürekli artan tüketimle birlikte pek çok atık oluşmaktadır. Bu atıkların miktarı ve zararlı içerikleri sebebiyle büyük bir çevre sorunu haline geldiği, çevre ve insan sağlığını tehdit ettiği belirtilmektedir. $\mathrm{Bu}$ nedenle atıkların geri kazanımı çevre ve insan sağlığının korunması açısından oldukça önemli bir yer tutmaktadır (Gündüzalp \& Güven, 2016). Dünya nüfusunun gittikçe artması ile beraber besin ihtiyaçlarının karşılanması da zorlaşmıştır. Tarımsal üretimi kısa vadede artırdığı için tarım ilacı ve kimyasal gübre kullanımını teşvik eden "Yeşil Devrim" hareketi, bütün dünyayı salgın bir hastalık gibi sarmıştır. $\mathrm{Bu}$ dönemin önemli ilaçları arasında, halk sağ lığından tarım zararlılarına kadar birçok alanda kullanılan dikloro difenil trikloroethan (DDT) yer almaktadır (Beard, 2006). Sonraki yıllarda aşırı ve bilinçsizce kullanılan kimyasalların, çevreyi ve canlı hayatı olumsuz olarak etkilediği ve onarılamaz boyutlarda zarar verebildiği bildirilmiştir. Kimyasal gübre kalıntıları su kaynaklarında, pestisit kalıntıları ise insan ve hayvanların besinlerinde tespit edilmiştir. Dolayısıyla kanserojen, mutajen ve teratojen etkilerin ortaya çıkması, farklı tarım yöntemlerine ihtiyaç duyulması gerekliliğini başlatmıştır (Baier-Anderson \& Anderson, 2000). Bununla beraber yoğun kimyasal kullanımı ile toprağın verimsiz hale gelmesi hızlanmış ve toprak flora ve faunası olumsuz bir şekilde etkilenmiştir. Bütün bu sebepler sonunda, tarımsal üretim için doğal dengeyi koruyucu ve bozulan doğayı yenileyebilecek yaklaşımlar aranmaya başlanmış ve organik yaklaşımlar ortaya çıkmıştır (Chen vd., 2001). Dünyada ve ülkemizde organik tarıma olan ilgi ve talep gün geçtikçe artış göstermektedir. Dolayısıyla tarımsal üretimde, kimyasal gübrelemeye alternatif olarak organik gübrelemenin kullanılması önem kazanmıştır (İlay vd., 2013). Organik gübreleme toprağın verimini, sürdürülebilirliğini ve su tutma kapasitesini artırmakta, toprağa bakım yapmakta, kanserojen riskini ortadan kaldırmakta ve mikrobiyal aktiviteleri hızlandırmaktadır (URL-1, 2007). Organik ve sürdürebilir tarım modelleri için topraktaki organik madde içeriğinin artırlabilmesinde ilk olarak, aeorobik termofilik kompostlarla çalışmalar yapılmıştır. $\mathrm{Bu}$ kompostlar bitkinin beslenmesi ve toprakta bulunan bitki patojenlerinin baskılanmasında önemli bir göreve sahiptir. $\mathrm{Bu}$ sebeple organik tarım uygulamalarında termofilik kompostlarla ilgili çalışmalar yoğunluk kazanmıştır (Boehm vd., 1993). Şehirleşmeden kaynaklanan olumsuz etkenler de kompost uygulamalarının yaygın hale gelmesine imkân vermiştir. Dolayısıyla kompost uygulamaları ile atıkların işlenmesi, sürdürülebilir hale gelmesi sağlanmaktadır. Ayrıca bunların çevre dostu ve ekonomik olması büyük bir avantaj olarak görülmektedir. Bununla beraber özellikle son yıllarda, evsel ve endüstriyel atıkların geri kazanımında solucanlar kullanılarak kompost elde edilebilmektedir.

Vermikompost olarak isimlendirilen bu mezofilik kompost, termofilik komposttan daha kisa sürede gerçekleşmekte, ürün ve işlem açısından daha iyi sonuç verebilmektedir (Dominguez vd., 1997). Vermikompost, organik atık ve artıkların bazı toprak solucanlarınca sindirilip dışkılanması sonucu oluşan işlem olarak tanımlanmaktadır. Solucanlar tarafindan sindirilen organik atıklar, hızlı bir şekilde humifikasyon ve detoksifikasyona tabi tutularak kömüre benzer bir materyal meydana gelmektedir (Kale vd., 1992). Vermikompost, mikroorganizmalar ile solucanların etkileşimiyle organik materyallerin biyodegradasyonu sonucunda elde edilmektedir. Vermikompostun bünyesinde fosfat, kalsiyum, nitrat, magnezyum ve potasyum bulunmaktadır (Joshi \& Pal Vig, 2010). Yeterli mineral elementler bulunduğunda, humik maddelerin bitkilerin gelişimine olumlu etkileri bulunmaktadır (Chen \& Aviad, 1990). Normal şartlarda vemikompostta \% 17-36 oranında humik madde bulunduğu belirtilmektedir (Orlov \& Biryukova, 1996). Hayvansal gübre, arıtma çamuru, kağıt endüstrisi atıklarından elde edilen vermikompostların yüksek miktarda humik maddeye sahip olduğu görülmüştür (Masciandro vd., 1997; Atiyeh vd., 2000). Solucanlar organik atıkları tüketirken, ortamda bulunan patojen bakterileri, mantarları, nematodları ve birçok yabancı ot tohumunu da tüketmektedir. Bununla beraber, solucan sindirim sistemi zararlı maddelerin büyük bir kısmını imha etmektedir. Solucanların sindirim atıkları tarafindan salgılanan maddeler ise ortamda bulunan pek çok zararının yapısını bozmakta ve farklı mikroorganizmalarca çabuk bir şekilde tüketilebilmektedir. $\mathrm{Bu}$ sebeple, vermikompost son ürünlerinde insan sağlığ i için sorun oluşturacak patojenler yer almamaktadır. Vermikompostlaşma işleminde zararlı patojenlerin büyük bir kısmı solucan tarafindan indirgenmekte ve vermicompost mikrobiyal biyotası canlı sağlığı için faydalı hale dönüşmektedir. Ayrıca, başlangıçtaki organik materyallerin bileşenleri ile solucanların kompostlanması sonucunda elde edilen vermikompostun besin maddesi kapsamının özellikleri, kimyasal ve fiziksel özellikleri açısından önemli derecede farklılıklar göstermektedir. Vermikompostlanmamış materyalle kıyaslandığında vermikompostun besin maddesi içeriği çok daha yüksek seviyelerdedir (Orozco vd., 1996; Erşahin, 2007b). Vermikompostun yüksek değerlikli olmasının en önemli sebepleri arasında, bitki için gerekli besin elementlerinin çözünmüş ve hemen kullanılabilir formda olması ve bakteri, fungus gibi birçok faydalı mikroorganizmayı içermesi yer almaktadır. Solucanların sindirim sisteminden doğal olarak dışarı atılan organik atıkların mikro besin elementleri, kolloidal bir formda oldukları için bitkilerce topraktan kolay bir şekilde alınmaktadır. Ayrıca vermikompostun amino asit, enzim, 
humik asit, fulvik asit gibi bitki gelişimi için gerekli organik bileşikleri içermesi, bitkiler için hormon aktivitesini artırarak hastalıklara karşı korumaktadır. Bununla beraber, simbiotik ve asimbiotik azot bağlayan bakterileri de içerdiğinden, topraktaki azot kazancını artırmaktadır. Bütün bu özellikler, vermikompostun organik gübre içinde önemli bir yere sahip olduğunu göstermektedir (Karaçal \& Tüfenkçi, 2010). Vermikompostun içermiş olduğu solucan mukusuyla çevrelenen besin elementleri yavaş bir şekilde salınmakta ve bitki tarafından hızlıca kullanılabilmektedir. Bu besinlerin yavaş çözünmesi besin elementlerinin kaybını engellemektedir. Ayrica vermikompostun su tutma kapasitesi, yüksek havalanma ve gözenekli yapıya sahip olması, iyi bir toprak düzenleyicisi olduğunu göstermektedir. Aerobik parçalanma sonrasında, solucanın sıvı olarak almış olduğu besinlerin sindirim sisteminde daha fazla parçalanması, bitkinin kullanacağı formda ve bitki için faydalı besin elementleri yönünden zengin bir özelliktedir (Buchanan vd., 1988). Vermikompost günümüzde tarımın sürdürülebilirlik özelliğini destekleyen yöntemler arasında ekonomik olarak oldukça yüksek öneme sahiptir. Buna ilaveten son yıllarda çevre için büyük tehlike oluşturan organik kökenli atıkların geri kazanılmasında vermikompostlaşma işlemi yoğun biçimde tercih edilmektedir (Manyuchi \& Phiri, 2013). Ayrıca vermikompost yöntemi, ticari ve ekolojik açıdan büyük öneme sahip ürünlerin elde edilmesini sağladığı için, tüm dünyada yoğun bir şekilde kullanılmaktadır (Punde \& Ganorkar, 2012). Vermikompost üretimi için evsel yemek atıkları, çay atıkları, ölü bitkiler, büyükbaş, küçükbaş ve farklı hayvan atıkları, endüstriyel atıklar, atık sulardaki çöpler, kanalizasyon içeriği gibi pek çok atık kullanılabilmektedir (Yüksek, 2019). Dünya genelinde organik atıklardan solucan gübresi ve canlı solucan üretimi çalışmaları hızla yaygınlaşmaktadır (Arıman Karabulut vd., 2016). Vermikompost tekniğiyle İngiltere'de hayvan, bitki ve endüstri atıklarının, Amerika'da ise kanalizasyon atıklarının işlenmesinde büyük yararlar elde edilmiştir (Neuhauser vd., 1988). Vermikompost üretiminde, aerobik kompost yığınları içerisinde sık bir şekilde kompost solucanları, bilimsel isimleriyle Eisenia fetida (tiger worm), Eisenia andrei (red tiger worm), Perionyx excavatus (Indian blue worm), Dendrobaena veneta, Lumbricus rubellus (red worm), Pheretoma excavatus, Eudrilus eugeniae (African nightcrawler), Herteroporodrilus spp. ve Fletcherodrilus spp. yer almaktadır. Bunlar içerisinde E. fetida, E. andrei ve D. veneta 1lıman bölgelere, $L$. rubellus ve $P$. excavatus ise sicak bölgelere daha iyi adapte olmaktadır. $\mathrm{Bu}$ beş tür organik artıkları daha iyi indirgediği için vermikompost çalışmalarında sıklıkla kullanılmaktadır. Ticari olarak en fazla tercih edilen tür E. fetida sonrasında ise L. rubellus türüdür (Edwards \& Bohlen, 1996).

Ülkemizdeki çay lifi atıklarının yaklaşık 3500040000 ton, tüketilen demlenmiş çay atığının ise yaklaşık 200 000 ton, yıllık budama ile oluşan çay atıklarının 500000 tonun üzerinde olduğu öngörülmektedir. Bu atıklara organik kökenli evsel ve diğer tarımsal atıklar eklendiğinde organik kökenli atık potansiyelinin oldukça yüksek bir seviyede olduğu görülmektedir. Bu atıkların vermikompostlaşma ile geri kazanılması durumunda bir yandan bu atıkların çevreyi kirletmesi önlenirken; diğer yandan bu atıklar ekonomik değeri olan ürüne dönüştürülerek ülke ekonomisine kazandırılabilecektir.

Çalışmanın amacı, demlenmiş çay atığı ve yemek atıklarının olduğu besi ortamlarında Eisenia fetida'nın gelişimi ve elde edilen katı solucan gübresindeki bazı besin elementlerinin tespit edilmesidir.

\section{MATERYAL ve METOT}

\section{Denemelerde kullanılan besi ortamlarının} seçilmesi ve denemelerin hazırlanması: Denemelerde kullanılan demlenmiş çay ve yemek atıkları Recep Tayyip Erdoğan Üniversitesi öğrenci- personel yemekhanesi ve kantinden sağlanmıştır. Denemelerde kullanılan yemek atıkları ve çay posası kapaklı özel kaplarda 3 ay süreyle çürütülerek kompoze hale getirilmeye çalışılmıştır. Araştırmada kullanılan fermente olmuş inek gübresi ve Kırmızı Kaliforniya Solucanı LAZUTIM Ticaret Şirketi tarafından sağlanmıştır. Deneme Deseni ve Yapılan Ölçümler: Araştırma, $40 \mathrm{~cm}$ en x $40 \mathrm{~cm}$ boy x $20 \mathrm{~cm}$ derinliğe sahip kasalarda tesadüf parselleri deneme desenine uygun ve üçer tekrarlı olarak yürütülmüştür (Tablo 1, Şekil 1). Denemelerde kullanılan besi ortamı ve katı solucan gübresi (vermicompost) ise Şekil 2'de sunulmuştur.

Tablo 1. Denemelerde kullanılan besi ortamı ve deneme deseni.

\begin{tabular}{lllll}
\hline Deneme No & Denemelerde Kullanılan Besi Ortamları & \multicolumn{3}{c}{ Tekrar Sayısı } \\
\hline A & Demlenmiş Çay Atığı (\% 100) & A1 & A2 & A3 \\
B & Yemek Atığı (\% 100) & B1 & B2 & B3 \\
C & Demlenmiş Çay Atığı (\% 50)+ Yemek Atığı (\% 50) & C1 & C2 & C3 \\
& Demlenmiş Çay Atığı (\% 40)+ Yemek Atığı (\% 40)+ & & & \\
D & İnek Gübresi (\%20) & D2 & D3 \\
& Demlenmiş Çay Atı̆̆ (\% 50)+ İnek Gübresi (\% 50) & E1 & E2 & E3 \\
E & Yemek Atığı (\% 50)+ İnek Gübresi (\% 50) & F1 & F2 & F3 \\
F & & & & \\
\hline
\end{tabular}

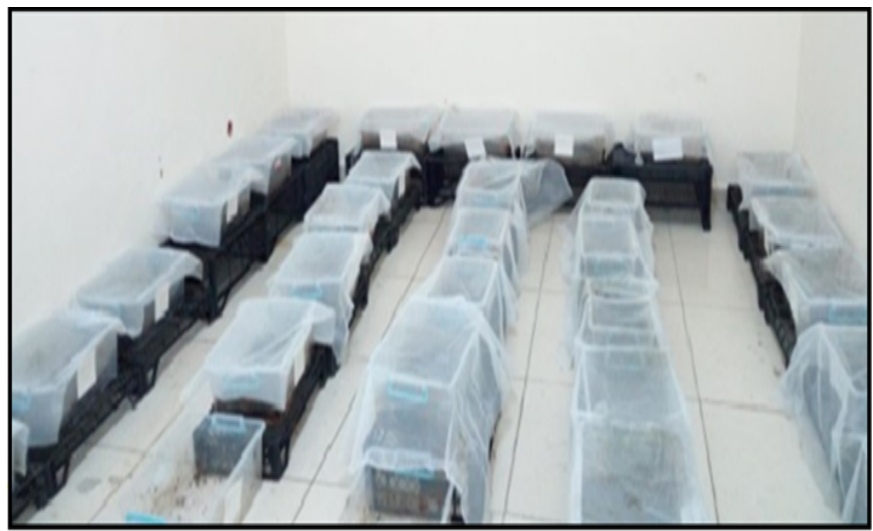

Şekil 1. Farklı besin ortamlarına göre solucan besleme kutuları. 


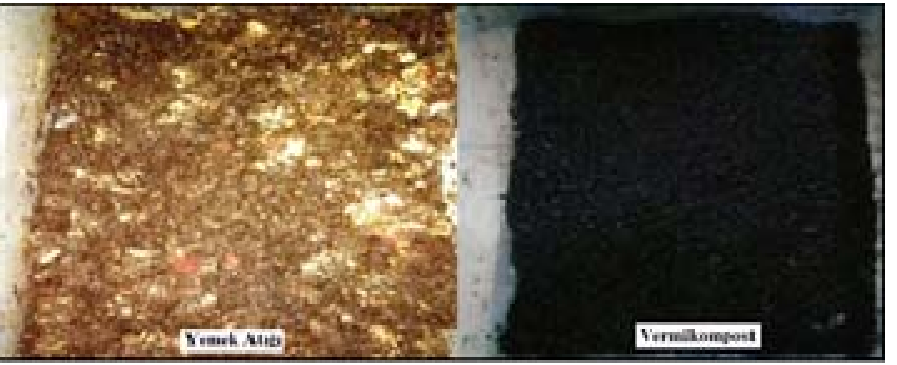

Şekil 2. Solucan beslemede kullanılan yemek atığ̀ ve katı solucan gübresi (vermicompost)

Tablo 2. Deneme gruplarının başlangıcında parsellerindeki solucan sayısı, ağırlığı ve verilen yem miktarları.

\begin{tabular}{|c|c|c|c|c|}
\hline Gruplar & $\begin{array}{l}\text { Denememeler Kullanılan Besin } \\
\text { Ortamları }\end{array}$ & $\begin{array}{l}\text { Solucan } \\
\text { sayis1 (adet) }\end{array}$ & $\begin{array}{l}\text { Solucan } \\
\text { Ağırlı̆̆ı (g) }\end{array}$ & $\begin{array}{l}\text { Yemin Ağırlı̆̆ } \\
(\text { Yem }+ \text { Su })(g)\end{array}$ \\
\hline A1 & \multirow{3}{*}{ Demlenmiş Çay Atığı (\% 100) } & 30 & 7,63 & 890 \\
\hline A2 & & 30 & 8,91 & 890 \\
\hline A3 & & 30 & 8,62 & 890 \\
\hline B1 & \multirow{3}{*}{ Yemek Atı̆̆ı (\% 100) } & 30 & 11,31 & 890 \\
\hline B2 & & 30 & 6,82 & 708 \\
\hline B3 & & 30 & 4,78 & 708 \\
\hline $\mathrm{C} 1$ & \multirow{3}{*}{$\begin{array}{l}\text { Demlenmiş Çay Atı̆̆ı (\% 50) + } \\
\text { Yemek Atığı }(\% \text { 50) }\end{array}$} & 30 & 8,31 & 708 \\
\hline $\mathrm{C} 2$ & & 30 & 9,37 & 708 \\
\hline C3 & & 30 & 9,21 & 804 \\
\hline D1 & \multirow{3}{*}{ 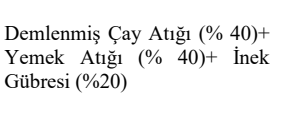 } & 30 & 9,03 & 804 \\
\hline D2 & & 30 & 8,73 & 804 \\
\hline D3 & & 30 & 8,12 & 804 \\
\hline E1 & \multirow{3}{*}{$\begin{array}{l}\text { Demlenmiş Çay Atığı (\% 50) + } \\
\text { İnek Gübresi (\%50) }\end{array}$} & 30 & 8,52 & 876 \\
\hline E2 & & 30 & 9,05 & 876 \\
\hline E3 & & 30 & 9,60 & 876 \\
\hline $\mathrm{F} 1$ & \multirow{3}{*}{$\begin{array}{l}\text { Yemek Att̆ğ1 }(\% 50)+\text { İnek } \\
\text { Gübresi }(\% 50)\end{array}$} & 30 & 7,87 & 876 \\
\hline $\mathrm{F} 2$ & & 30 & 8,68 & 876 \\
\hline F3 & & 30 & 8,16 & 876 \\
\hline
\end{tabular}

Daha sonra ilgili kaplara granül haldeki kompost besi malzemesi konulmuştur. Kompost besi ortamlarındaki, solucan sayıları ve ağırlıklarına ait bilgiler Tablo 2'de verilmiştir. İlgili besi ortamlarının her birine ağırlıkları belirlenmiş 30 adet Kırmızı Kaliforniya solucanı yerleştirilmiştir. Her gün günde $3 \mathrm{kez}$ olmak üzere nem ölçümleri yapılarak besi ortamındaki nem değerleri araştırma süresince \% 50 \pm 5 seviyesinde tutulmuştur (Yüksek, 2016; Yüksek vd., 2017; Yüksek, 2019). Araştırma devam ederken 30 Nisan, 30 Mayıs ve 26 Haziran'da her bir deneme parselindeki solucanların sayımı yapılmış ve toplam ağırlıkları belirlendikten sonra yeniden besi ortamlarına konulmuştur. Araştırma 8 hafta sürdürülmüş ve deneme parsellerindeki atıkların solucan tarafından sindirilmesi ve vermicompostlaşma işlemi sonucunda deneme kaplarının her birinden yeter miktarda vermicompost örneği alınarak bazı analizlerin (nem, yanma kaybı, pH, EC, Toplam azot, fosfor, potasyum, kalsiyum, demir, mangan, çinko ve bakır yapılması için Atatürk Çay ve Bahçe Kültürleri Araştırma Enstitüsü Müdürlüğü Laboratuvarına gönderilmiştir.

Laboratuvar Analizleri: Vermikompost analizinde her bir vermikompost numunelerinden 1'er gram tartılmıştır.
Tartılan numuneler teflon kaplara alınarak üzerine 2,35 ml \% 65 lik $\mathrm{HNO}_{3}$ ve $7 \mathrm{ml} \% 30$ ' luk $\mathrm{HCl}$ eklenmiştir. Daha sonra teflon kapların kapakları kapatılarak 2 dakika bekletilmiş ve süre sonunda ilgili numuneler Berghof marka speed wave (mikrodalga)cihazına yerleştirilerek uygun programda çalıştırılmıștır. Mikrodalga fırında yaş yakma işlemi tamamlanan numuneler sıvı ortama aktarılmış ve üzerine saf su ilave edilerek 100 ml'ye tamamlanmıștır. Elde edilen çözelti falkon tüplere konularak Pelkin Elmer Marka, Optima 7000 DV Model, ICP-OES cihazında ve milyonda bir hassasiyetle (ppm düzeyinde) ağır metal değerleri okunmuştur. Azot Analizi, Kjeldahl yöntemine göre AOAC 990.03 (AOAC, 2000), TS 8337 ISO 11261 metotlarına göre, pH analizi, AOAC 981.12 TS EN 159332'e göre, kuru madde analizi AOAC 932.12'ye göre yapılmıştır.

Değerlendirme Yöntemleri: Farklı niteliklerdeki kompost materyalin, solucanın çoğalmasına, solucan biyokütle değişimine ve gübre kalitesine (gübredeki bazı besin elementlerine) etkisi varyans analizi ile test edilmiştir (Yüksek vd., 2017; Yüksek, 2019). Farklı besin ortamlarında solucan sayısının ve ağırlığının zamana göre değişimi regresyon denklemleri ile ortaya konulmaya çalışılmıştır. Besi ortamlarına göre solucan sayısı ve biyokütle ile elde edilen gübredeki bazı besin elementlerinin karşılaştırılmasında Duncan testi kullanılmıştır. Veriler SPSS-23 paket programında değerlendirilmiştir.

\section{BULGULAR ve TARTIŞMA}

Solucan Sayısı ve Ăğırlı̆̆ında Meydana Gelen Değişim: Araştırma sonucunda deneme kaplarındaki yemek hacmin $\% 50$ veya daha fazla olduğu $\mathrm{B}, \mathrm{C}$ ve $\mathrm{F}$ besi ortamlarında solucanların yaşamadığı görülmüştür. Araştırma sonucunda A, D ve E besi ortamlarındaki solucan sayıları ve ağırlıkları saptanmıştır. Besi ortamlarındaki solucan sayılarının zamana bağlı olarak değişimlerinin düzensiz olduğu belirlenmiştir. \%100 Demlenmiş çay atığından oluşan A besi ortamındaki solucan sayısı önce azalmış, sonra tekrar artmıştır. Araştırmanın başlangıcına göre ise solucan sayısı azalmıştır. \%40 Demlenmiş çay atığ1 $+\% 40$ Yemek atığ +\%20 inek gübresi karışıma sahip olan D besi ortamındaki solucan sayısı zamana göre doğrusal biçimde azalırken; \%50 Demlenmiş çay atığ 1 \% 50 İnek gübresi karışımından oluşan E besi ortamındaki solucan sayısı önce hafif azalmış, daha sonra tekrar artmıştır. Araştırma sonucunda en yüksek solucan sayisina 37 adet solucan ile E besi ortaminda; en düşük solucan sayısına 12 adet ile $\mathrm{D}$ besi ortamında rastlanmıştır (Tablo 3). Farklı besi ortamlarına deneme kaplarındaki solucan ağırlıklarının değişimi düzensiz olmuştur. A besi ortamındaki solucan ağırlığı 4 ve 8 . haftalarda doğrusal biçimde artarken; $\mathrm{D}$ ve $\mathrm{E}$ besi ortamlarındaki solucan ağırlıkları önce artmış, sonra tekrar azalmıştır (Tablo 3). A besi ortamında 1 adet solucanın ortalama ağırlı̆̆ı 4. ve 8. haftalarda doğrusal bir şekilde artmıştır. Solucan ağırlığında zamanla meydana gelen 
değişim: $R^{2}=0,792$ ile $Y=0,1043 x+0,2061$ şeklindedir. Formülde Y: Solucan Ağırlığı, X: Zamanı (hafta sayısı) ifade etmektedir. D (\%40 Demlenmiş çay atığ1 $+\% 40$ yemek atığ1 $+\% 20$ inek gübresi) besi ortamında solucan sayısı zamana bağlı olarak 4. haftada yaklaşık 17'e, 8 . haftada ise yaklaşık 12 adede düşmüştür. Buna göre, solucan sayısında zamanla meydana gelen değişim: $\mathrm{Y}=-9 \mathrm{X}+37,889$ ile $\mathrm{R}^{2}=0,9563$ şeklindedir (Y: Solucan Sayısı, X: Zaman). D besi ortamındaki 1 adet solucanın ortalama ağırlığı 4. ve 8 . haftalarda artış göstermiştir. Solucan ağırlığında zamanla meydana gelen değişim: $R^{2}=0,841$ ile $Y=0,1632 x+0,1653$ şeklindedir. Formülde Y: Solucan Ağırlığını, X: Hafta sayısını ifade etmektedir. E (\%50 demlenmiş çay atığ $1+\% 50$ inek gübresi) besi ortamındaki kaplardaki solucan sayısı önce yaklaşık \%4 azalmış, sonra \%25 artmıştır. Solucan sayısında zamanla meydana gelen değişim: $\mathrm{R}^{2}=0,649$ ile $\mathrm{Y}=$ $3,6667 \mathrm{x}+24,778$ şeklindedir. Formülde $\mathrm{Y}$ : Solucan Ağırlığını, X: Hafta sayısını ifade etmektedir. 1 adet ortalama solucan ağırlığı 4. haftada ciddi bir şekilde (\%98) artmıştır. 8 . haftada ise başlangıçtaki ağırlığından \% 7 oranda azaldığı tespit edilmiştir. Ortalama değerlere göre en fazla solucan sayısı 32,11 adet ile E besi ortamında (\%50 Demlenmiş çay atığ $1+\% 50$ İnek gübresi), en düşük solucan sayısı ise 19,88 adet ile D besi ortamında (\% 40 Demlenmiş çay atığ $1+\% 40$ Yemek atığ $1+\% 20$ İnek gübresi) görülmüştür.

Solucan sayısı bakımından (D-E) besi ortamlarında $\mathrm{p} \leq 0.01$ yüksek düzeyde istatistiksel olarak anlamlı fark olduğu tespit edilmiştir. Solucan ağırlığı bakımından en yüksek değere 12,30 gr ile E besi ortamında, en düşük değere ise 8,74 gr ile D besi ortamında ulaşılmıştır (Tablo 3)
Farklı Besi Ortamlarindan Elde Edilen Gübrelerdeki Bazı Besin Elementlerinin Değişimi: Farklı besi ortamlarından elde edilen katı solucan gübresinde en yüksek azot (N) miktarına \% 2,16 ile A (\% 100 demlenmiş çay atığı) besi ortamında, en düşük azot miktarına ise \% 1,27 ile D (\% 40 demlenmiş çay atığ $1+\% 40$ yemek atığ $1+\% 20$ inek gübresi) besi ortamında rastlanmıştır. Azot değerleri bakımından (D-A), (D-E), ve (E-A) besi ortamları arasında $p$ $\leq 0.05$ önem seviyesinde anlamlı fark olduğu belirlenmiştir (Tablo 4). Besi ortamlarından elde edilen en yüksek fosfor (P) miktarı 1633,33 ppm ile E (\% 50 demlenmiş çay atığ $1+$ \% 50 inek Gübresi) besi ortamında, en düşük $\mathrm{P}$ miktarı ise 1100 ppm ile D besi ortamında rastlanmıştır. P miktarlarına göre (A-D***), (A-E***), (D-E***) besi ortamlarında $\mathrm{p}$ $\leq 0.001$ seviyesinde çok yüksek düzeyde anlamlı fark olduğu belirlenmiştir (Tablo 4).

Tablo 3. Solucan sayısı ve ağırlıklarının besi ortamlarına göre değişimi.

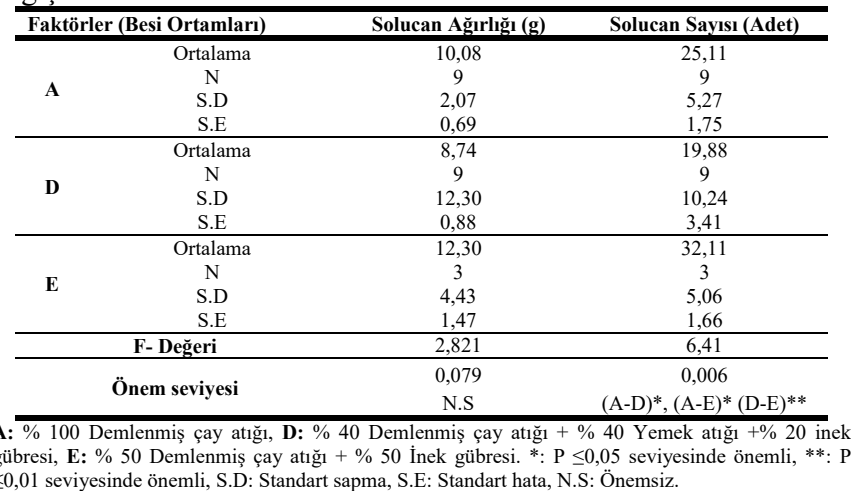
$\leq 0,01$ seviyesinde önemli, S.D. Standart sapma, S.E: Standart hata, N.S: Önemsiz.

Tablo 4. Farklı besi ortamlarına göre mineral maddelerin ve pH'ın değişimi.

\begin{tabular}{|c|c|c|c|c|c|c|c|c|c|c|c|}
\hline \multicolumn{2}{|c|}{ Faktörler } & $\mathrm{N}$ & $\mathrm{P}$ & $\mathrm{K}$ & $\mathrm{Zn}$ & $\mathrm{Ca}$ & $\mathrm{Cu}$ & $\mathrm{Fe}$ & $\mathrm{Mn}$ & $\mathrm{Mg}$ & $\mathrm{pH}$ \\
\hline \multirow{2}{*}{ A } & Ort. & 2,16 & 400 & 3600 & 18,75 & 3429,01 & 7,06 & 285 & 1068,5 & 1312,15 & 7,30 \\
\hline & SD & 0,32 & 200 & 360,55 & 3,39 & 624,88 & 1,7 & 54,28 & 104,54 & 126,49 & 0,09 \\
\hline \multirow{2}{*}{$\mathrm{D}$} & Ort. & 1,26 & 1100 & 4970 & 32,46 & 4469,43 & 6,25 & 1843,46 & 337,11 & 1799,05 & 7,91 \\
\hline & $\mathrm{SD}$ & 1,50 & 264,57 & 3429,82 & 3,88 & 49,607 & 0,45 & 209,32 & 18,20 & 169,03 & 0,09 \\
\hline \multirow{2}{*}{$\mathrm{E}$} & Ort. & 1,65 & 1633,33 & 3816 & 40,61 & 4640,16 & 10,66 & 3439,95 & 500,11 & 1967,80 & 8,02 \\
\hline & SD & 0,57 & 57,73 & 4751,23 & 8,16 & 109,89 & 2,28 & 544,74 & 63,57 & 90,87 & 0,18 \\
\hline \multirow{3}{*}{\multicolumn{2}{|c|}{$\mathrm{F}$}} & 3,99 & 30,38 & 0,142 & 11,77 & 9,55 & 5,86 & 65,2 & 86,702 & 19,745 & 25,38 \\
\hline & & 0,079 & 0,001 & 0,871 & 0,008 & 0,014 & 0,037 & 0 & 0 & 0,002 & 0,001 \\
\hline & & N.S & $(\mathrm{A}-\mathrm{D}) * * *$ & N.S & $(\mathrm{D}-\mathrm{A})^{* * *}$ & $(A-D)^{*}$ & $(\mathrm{D}-\mathrm{E})^{*}$ & $(\mathrm{~A}-\mathrm{D}) * * *$ & $(\mathrm{D}-\mathrm{E})^{* * *}$ & $(\mathrm{~A}-\mathrm{D})^{* *}$ & $(A-D) * *$ \\
\hline \multirow{2}{*}{\multicolumn{2}{|c|}{ Önem seviyesi }} & N.S. & $(\mathrm{A}-\mathrm{E}) * * *$ & & $(\mathrm{E}-\mathrm{A})^{* * *}$ & $(\mathrm{~A}-\mathrm{E})^{*}$ & $(\mathrm{~A}-\mathrm{E})^{*}$ & $(\mathrm{~A}-\mathrm{E}) * * *$ & $(\mathrm{~A}-\mathrm{D}) * * *$ & $(\mathrm{~A}-\mathrm{E})^{* *}$ & $(\mathrm{~A}-\mathrm{E}) * *$ \\
\hline & & & $(\mathrm{D}-\mathrm{E}) * * *$ & & & & & $(\mathrm{D}-\mathrm{E}) * * *$ & $(\mathrm{E}-\mathrm{A}) * * *$ & & \\
\hline
\end{tabular}

A: \% 100 Demlenmiş çay atığı, D: \% 40 Demlenmiş çay atığ $+\% 40$ Yemek atığ $1+\% 20$ inek gübresi, E: \% 50 Demlenmiş çay atı̆̆ $+\% 50$ İnek gübresi. *: P $\leq 0,05$ seviyesinde önemli, **: $\mathrm{P} \leq 0,01$ seviyesinde önemli, ***: $\mathrm{P} \leq 0,001$ seviyesinde önemli, N.S: Önemsiz.

En yüksek potasyum (K) miktarlarına 4970 ppm ile $\mathrm{D}$ besi ortamında, en düşük K miktarına ise 3600 ppm ile A besi ortamında ulaşılmıştır. Ancak, Potasyum değerleri bakımından besi ortamları arasında istatistiksel olarak anlamlı bir fark bulunmamıştır (Tablo 4). Çinko (Zn) miktarları en yüksek 40,61 ppm, en düşük 18,75 ppm olarak belirlenmiştir. Zn miktarları bakımından en yüksek değer $\mathrm{E}$ besi ortamında, en düşük değer ise A besi ortamında tespit edilmiştir. Besi ortamlarına göre (A-E***), (D-A***), arasında $\mathrm{p} \leq 0.001$ seviyesinde çok yüksek düzeyde anlamlı fark tespit edilmiştir (Tablo 4). Besi ortamlarındaki en yüksek kalsiyum (Ca) 4640,16 ppm ile E besi ortamında, en düşük $\mathrm{Ca}$ ise $3429,02 \mathrm{ppm}$ ile $\mathrm{A}$ besi ortamında belirlenmiştir. Kalsiyum değerleri bakımından (A-D*) ve (A$\left.E^{*}\right)$ besi ortamları arasında $p \leq 0.05$ seviyesinde önemli fark olduğu saptanmıştır (Tablo 4).

Bakır $(\mathrm{Cu})$ miktarları bakımından en fazla bakır 10,66 ppm ile E besi ortamında, en düşük değer 7,06 ppm ile A besi ortamında belirlenmiştir. Bakır değerleri bakımından $\left(D-E^{*}\right)$ ve $\left(A-E^{*}\right)$ arasinda $(p \leq 0.05)$ önem seviyesinde fark 
olduğu belirlenmiştir. Demir $(\mathrm{Fe})$ değerleri bakımından en yüksek miktar olan 3439,95 ppm'e E besi ortamında, en düşük miktar olan 285,00 ppm'e A besi ortamında rastlanmıştır. (A-D***), (A-E***), (D-E**) besi ortamları arasında $\mathrm{p} \leq 0.001$ seviyesinde çok yüksek düzeyde anlamlı fark olduğu görülmüștür (Tablo 4). Besi ortamlarından elde edilen en yüksek Manganez (Mn) miktarına 1068,50 ppm ile A besi ortamında, en düşük Mn miktarına 337,11 ppm ile D besi ortamında rastlanmıştır. Besi ortamlarına göre (A$\left.\mathrm{D}^{* * *}\right),\left(\mathrm{A}-\mathrm{E}^{* * *}\right),\left(\mathrm{D}-\mathrm{E}^{* * *}\right)$ arasinda $\mathrm{p} \leq 0.001$ seviyesinde fark olduğu belirlenmiştir. En yüksek Magnezyum (Mg) miktarı 1967,80 ppm ile E besi ortamında, en düşük $\mathrm{Mg}$ miktarı 1312,15 ppm ile A besi ortamında belirlenmiştir. (A$\left.\mathrm{D}^{* *}\right)$, (A-E**) besi ortamları arasında $\mathrm{p} \leq 0.01$ yüksek düzeyde anlamlı fark olduğu tespit edilmiştir (Tablo 6 ve 7). En yüksek pH değerine 8,02 ile $\mathrm{E}$ besi ortamında, en düşük $\mathrm{pH}$ değerine ise 7,30 ile $\mathrm{A}$ besi ortamında rastlanmıştır. $\mathrm{pH}$ değerleri bakımından (A-D**), (A-E**) arasında $\mathrm{p} \leq 0.01$ yüksek düzeyde anlamlı fark olduğu belirlenmiştir (Tablo 4).

Çalışma üç tekerrürlü olarak 6 farklı besi ortamında gerçekleştirilmiştir. Deneme $3 \mathrm{kez}$ tekrarlanmasına rağmen bu besi ortamlarından \% 50 oranında yemek atığı bulunan ortamlarda solucanların hayatlarını devam ettiremedikleri görülmüştür. Dolayısıyla, besi ortamındaki yüksek oranda yemek atıklarının kısmen ya da tamamıyla kompoze olmamış olmasının, solucan büyümesi ve yaşamasını olumsuz yönde etkilediği söylenebilir. Literatürde de, tam kompoze olmamış besi ortamları içerisindeki yüksek azot ve mineral maddelerin solucan ölümlerinde etkili olabileceği bildirilmiştir. Besi ortamlarındaki kompoze işlemi devam ederken açığa çıkan amonyum ve bunun artmasıyla geçici olarak artan $\mathrm{pH}$ ve yüksek miktarda parçalanabilir karbonhidratın da solucanları öldürebileceği belirtilmiştir (Sherman, 2003). Shanmugasundaram vd. (2013), E. fetida'nın bazı toksik gazlar ve yüksek alkalinite sebebiyle, keçi dışkısında yaşayamadığını tespit etmişlerdir. Araştırmada en yüksek biyokütle oluşumuna sığır gübresi ve çay atıklarında, sonrasında ise sığır gübresinde ulaşmışlardır. En düşük solucan ağırlığına ise at gübresinde olduğu sonucunu belirlemişlerdir. Bununla beraber at gübresine çay atıkları eklediklerinde biyokütlenin 4,3 kat, sığır gübresi eklediklerinde 5,3 kat arttığı saptamışlardır. Çay atıklarının tek başına kullanılarak elde edildiği biyokütlenin, sığır gübresi eklenerek elde edilen karışımdan 2,2 kat daha küçük olduğu tespit edilmiştir. Çalışmamızda, eşit oranda karıştırılan sığır gübresi ve demlenmiş çay atıkları ile en yüksek solucan ağırlıklarına ulaşılması, literatürle uyumluluk göstermektedir. Parthasarathi (2007), solucan biyokütlesi ve üremesi arasında pozitif bir ilişki olduğunu belirlemiştir. Aynı şekilde, Shanmugasundaram vd. (2013) yapmış oldukları çalışmada sığır gübresinde daha fazla genç solucan ürediğini ve biyokütlenin arttığını gözlemleyerek, aralarında pozitif bir ilişkiye ulaşmışlardır. Çay atıkları ve at gübresi karışımında ise minimum üremenin gerçekleştiğini kaydetmişlerdir. Çalışmamızda en fazla solucan sayısı ve solucan ağırlıklarına sığır gübresi ve demlenmiş çay atıkları olan besi ortamın da ulaşılması da, literatürdeki gibi pozitif bir ilişki olduğunu göstermektedir. Bu çalışmada, farklı besi ortamları kullanılarak, solucan gübrelerinin bazı besin elementlerinin değişimi incelenmiștir. Bu besi ortamlarından en yüksek N miktarına \% 100 Demlenmiş çay atığında, en yüksek P miktarına \% 50 Demlenmiş çay atı̆̆ $+\% 50$ inek gübresi ortamlarında ulaşılmıștır. Azot zenginliği, mineralizasyon prosesindeki atıkların amonyum ve nitratın dönüşümündeki kinetiğe bağlı olarak değiștiği ifade edilmiştir. Ayrıca, biyokütlenin net kaybı, degradasyon proseslerinde atıkların N zenginliğine katkı sağlamaktadır (Huang vd., 2004). Solucan gübresinin elde edilmesinde, solucanlar ile mikroorganizmaların kombinasyonu sırasında P miktarının artmasında temel sebebin, organik asitlerin ve enzimlerin miktarındaki artış olduğu düşünülmektedir (Das vd., 2016).

Garg vd. (2006) ise mutfak atığı, tarımsal atık, kurumsal atık ve tekstil endüstri çamuru atıklarını organik substrat olarak kullanarak solucan gübresi elde etmişlerdir. $\mathrm{N}$ oranını kontrol ile kıyaslandığında 4,4 - 5,8 kat, P oranını kontrol ile karşılaştırıldığında 1,4 - 6,5 kat artış gösterdiğine sonucuna ulaşmışlardır. Toplam organik karbonun en fazla tarımsal atıklarda (3 kat), sonrasında mutfak atıklarında $(2,2$ kat), en son ise tekstil endüstrinin atıklarında (1,5 kat) azalma gösterdiği tespit etmişlerdir. Dolayısıyla, evsel ve tarımsal atıklar kullanılarak elde edilen solucan gübresine ek olarak, endüstriyel atıkların kullanımı ile de solucan gübresi oluşturulmasının ekolojik olarak büyük bir fayda sağlayacağını ve tarımsal ihtiyacın giderime katkı sağlayacağını ifade etmişlerdir. Arancon ve ve Edwards (2011), sığır gübresi vermikompostunda $\% 1,90 \mathrm{~N}$ olduğunu saptamışlardır. Çalışmada sığır gübresine ek olarak demlenmiş çay atığı kullanılarak elde edilen vermikompostta $\% 1,65 \mathrm{~N}$, sığır gübresine hem demlenmiş çay atı̆̆ hem yemek atı̆̆ eklenerek oluşturulan vermikompost içerisinde ise \% 1,27 N elde edilmiştir. Dolayısıyla literatürde yer alan ve sadece sığır gübresi kullanılarak elde edilen vermikomposttaki N miktarının, çalışmada kullanılan karışım besi ortamlarından oluşturulan vermikomposttan daha yüksek olduğu görülmektedir. Bununla beraber sadece demlenmiş çay atığı kullanılarak elde ettiğimiz vermikompostta \% 2,16 $\mathrm{N}$ bulunması demlenmiş çay atığından elde edilen vermikompostun azot içeriği açısından literatürden daha yüksek olduğunu göstermektedir. Arancon ve Edwards (2011) sığır gübresi kullanarak elde ettikleri vermikomposta 23 ppm Ca, 3454 ppm Fe, 5802 ppm Mg, 160 ppm Mn, 516 ppm Zn'ye ulaşmışlardır. Çalışmamızda sığır gübresi ve demlenmiş çay atığı kullanılarak elde edilen vermikompostta 4640,17 ppm Ca, 3439,95 ppm Fe, 1967,80 ppm Mg, 500,12 ppm Mn, 40,62 ppm Zn belirlenmiştir. Sığır gübresi, demlenmiş çay atı̆̆ ve yemek atı̆̆ içeren vermikompost içerisinde ise 4469,43 ppm Ca, 1843,47 ppm Fe, 1799,06 ppm Mg, 337,12 ppm Mn, 32,47 ppm Zn tespit edilmiştir. Çalışmada literatürden farklı olarak $\mathrm{Ca}$ ve $\mathrm{Mn}$ miktarının 
yüksek, $\mathrm{Mg}$ ve $\mathrm{Zn}$ miktarının düşük olduğu görülmektedir. Fe miktarı ise sığır gübresine sadece demlenmiş çay atı̆̆ eklenilerek elde ettiğimiz vermikomposttaki ile benzerlik göstermektedir. Bellitürk vd. (2014), sığır gübresi ve zeytin budama atı̆̆ından elde ettikleri vermikompostta \% 1,62 N, 3,75 ppm Ca, 12653 ppm Fe, 0,47 ppm Mg, 525 ppm Mn, $104 \mathrm{ppm} \mathrm{Zn}$ belirlemişlerdir. Çalışmada sığır gübresi ve demlenmiş çay atığından elde ettiğimiz vermikompostta \% $1,65 \mathrm{~N}$ belirlenmesi literatür ile benzerlik göstermektedir. Ancak, çalışmada bu besi ortamını kullanılarak elde edilen vermikompostun $\mathrm{Ca}$ ve $\mathrm{Mg}$ miktarları daha yüksek, $\mathrm{Fe}$ ve $\mathrm{Zn}$ miktarları daha düşük olduğu görülmüștür. Araştırma sonucunda elde edilen $\mathrm{Mn}$ değerleri literatürle benzerlik göstermektedir. Lange (2005), gıda ve bahçe atığı vermikompostunda \% 1,81 N, 0,28 ppm Ca, 1440 ppm Fe, $2100 \mathrm{ppm} \mathrm{Mg}, 346$ ppm Mn, $387 \mathrm{ppm} \mathrm{Zn}$ olduğunu tespit etmiştir. Araştırma sonucunda demlenmiş çay atığından elde edilen vermikompostta $\% 2,16 \mathrm{~N}, 3429,02 \mathrm{ppm} \mathrm{Ca}, 285 \mathrm{ppm}$ $\mathrm{Fe}, 1312,15$ ppm $\mathrm{Mg}, 1068,50 \mathrm{ppm} \mathrm{Mn}, 18,75 \mathrm{ppm} \mathrm{Zn}$ belirlenmiştir. Literatürle karşılaştırıldığında demlenmiş çay atığından elde edilen vermikompostta N, Ca ve Mn miktarları yüksek, $\mathrm{Fe}, \mathrm{Mg}$ ve $\mathrm{Zn}$ miktarlarının ise düşük olduğu görülmüştür.

Suthar vd. (2016), su marulu ve inek gübresi farklı oranlarda karıştırarak dört farklı besi ortamı oluşturmuşlardır. Bunlardan elde ettikleri solucan gübresinin $\mathrm{N}$ içeriğinin, inek gübresinden daha fazla olduğunu belirlemişlerdir. Bununla beraber en yüksek $\mathrm{N}$ içeriğine su marulu konsantrasyonunun en yüksek olduğu besi ortamında ulaşmışlardır. Burada su marulunun içerisinde yer alan azot içeriğinin katkısından olduğunu ifade etmişlerdir. Aynı çalşsmada, solucan gübresinin elde edilmesi sirasında P miktarında da artış olduğu belirlenmiştir. Suthar vd. (2016), solucanların P mineralizasyonunda pozitif rollerinin olduğunu bildirmişlerdir. Vermicompostlaşma ile birlikte $\mathrm{K}$ ve Ca miktarında da artış görmüşler ve bu elementlerin miktarında ilk ve son içeriğin istatiksel olarak önemli olduğunu belirtmişlerdir. Aynı zamanda $\mathrm{Fe}, \mathrm{Cu}, \mathrm{Zn}$ gibi pek çok elementin de inek gübresi ile karşılaştırıldığında karışım atıklardan elde edilen solucan gübresinde daha fazla olduğunu görmüşlerdir. Çalışmamızda da solucan gübresinin elde edilmesinde, Suthar vd. (2016) çalışmalarındaki gibi karışım besi ortamlarında elementlerin miktarlarında artış görülmüştür. En yüksek K ve Ca miktarı \% 50 demlenmiş çay atığ $1+\% 50$ inek gübresi kullanımıyla meydana getirilen vermikompostta görülmüştür. $\mathrm{Fe}, \mathrm{Cu}, \mathrm{Zn}, \mathrm{Mn}, \mathrm{Mg}$ miktarlarının da besi ortamları arasında istatiksel olarak önemli olduğu sonucuna ulaşılmıştır. Bu sebeple, çalışmamız elementler açısından literatürle karşılaştırıldığında benzerlik göstermektedir. Yüksek $(2016,2019)$, farklı besi ortamları elde ettikleri solucan gübresinde en yüksek $\mathrm{N}, \mathrm{P}$ ve $\mathrm{Mn}$ miktarlarına \% 100 çay lifi, en yüksek K miktarına \% 100 Fındık zurufu, en yüksek Fe miktarına Fındık zurufu (\%50) + Çay lifi (\% 50) besi ortamlarında ulaşmışır. Dolayısıyla, organik atıklardan elde edilen solucan gübresinde, atıkların kompoze durumlarının gübre içeriği üzerinde oldukça önemli olduğu belirtilmiştir. Bazı araştırıcılar solucan gübresindeki organik madde kaybı ve atık karışımların ağırlığındaki azalmanın elementlerin ( $\mathrm{Fe}, \mathrm{Zn} \mathrm{Cr}$ gibi) artmasındaki ana faktör olduğunu belirtmişlerdir (Wang vd., 2013). Suthar vd. (2014), elementlerin temel olarak atık karışımlarında organik olarak bağlı formlar ve çözünebilir formlarının miktarı, ara organik asitlerin oluşumu, organik madde degradasyon oranı gibi serbest bırakılmasına bağlı olduğunu belirtmiştir.

\section{SONUÇLAR}

Çalışmanın sonucunda; ortalama değerlere göre en yüksek solucan sayısına E (\% 50 demlenmis çay atığı 1 \% 50 inek gübresi) besi ortamında, en düsük solucan sayısına ise D (\% 40 demlenmiş çay atı $\breve{g}_{1}+\% 40$ yemek atı̆ ${ }_{1}+\% 20$ inek gübresi) besi ortamında ulaşılmıştır. En yüksek ortalama solucan ağırlığına $\mathrm{E}(\% 50$ demlenmiş çay atığ $1+\% 50$ inek gübresi) besi ortamında, en düşük ortalama solucan ağırlığına ise $\mathrm{D}(\% 40$ demlenmiş çay atığ $1+\% 40$ yemek atığ $1+\% 20$ inek gübresi) besi ortamında rastlanılmıştır. Farklı besi ortamlarından elde edilen solucan gübrelerindeki en yüksek $\mathrm{N}$ miktarına \% 2,16 ile A (\% 100 demlenmiş çay atığı) besi ortamında, en düşük $\mathrm{N}$ miktarına ise $\mathrm{E}$ besi ortamında ulaşılmıştır. Besi ortamlarından elde edilen en yüksek $\mathrm{P}$ ve $\mathrm{K}$ miktarlarına $\mathrm{E}$ besi ortamında rastlanmıştır. En yüksek $\mathrm{Ca}$, $\mathrm{Zn}, \mathrm{Cu}, \mathrm{Fe}, \mathrm{Mg}$ değerlerine $\mathrm{E}$, en yüksek $\mathrm{Mn}$ değerine ise $\mathrm{D}$ besi ortamlarında ulaşılmıştır. Solucan gübresinin elde edilmesi için, büyümeyi destekleyen $\mathrm{Ca}, \mathrm{K}, \mathrm{Mg}, \mathrm{Na}, \mathrm{Fe}, \mathrm{Zn}$, $\mathrm{Cu}$ gibi elementlerin ve yüksek protein ve karbonhidrat içeriğinin yer aldığı atıkların tercihi, solucan biyokütlesinin artmasını desteklemektedir. Bununla beraber, degradasyon prosesinde $\mathrm{CO}_{2}, \mathrm{NO}_{\mathrm{x}}, \mathrm{NH}_{4}$, organik asitler ve diğer ara ürünler gibi toksik maddelerin üretilmesi, solucanların atı karışımlarında ölmelerine neden olmaktadır. Bu sebeple solucan biyokütlesinin oluşumunda ve vermikompostun elde edilmesinde atıkların içerikleri ve konsantrasyonu büyük bir önem oluşturmaktadır. Ayrıca kompoze işlemi ve süresinin de önemli bir etkiye sahip olduğu düşünülmektedir. $\mathrm{Bu}$ nedenle, farklı besi ortamlarında kompost aşamasında optimum süre ve ideal kompostlama işleminin doğru bir şekilde tespit edilmesi nihai ürün olan katı solucan gübresinin kalitesinin ortaya konulması için son derece önemlidir. Farklı organik atıklar için ideal kompost yöntemi ve kompostlaşma sürelerinin mutlaka araştırmalarla ortaya konulması gerekir. Demlenmiş çay atıklarının solucan gübresinin elde edilmesinde kullanılmaması ve solucan gübresinin içerisindeki bazı besin elementlerinin belirlenmesi üzerine yapılan bu çalışma, Türkiye'de konuyla alakalı yapılmış olan ilk çalışma olması açısından oldukça önemlidir. Ancak ülkemizde farklı organik atıklar kullanılarak katı ve sıvı solucan gübresinin elde edilmesi, elde edilen gübrelerin toprak kalitesi ve bitki gelişimi üzerindeki etkilerini ortaya koyacak yeni araştırmalara ihtiyaç vardır. Bu araştırmalardan elde edilecek yeni veriler yardımıyla ekolojik, ekonomik ve 
tarımsal açıdan pek çok faydaya ulaşılacağı düşünülmektedir. Dolayısıyla bu alandaki çalışmaların artırılması faydalı olacaktır.

\section{TEŞEKKÜR}

$\mathrm{Bu}$ çalışma Recep Tayyip Erdoğan Üniversitesi, Bilimsel Araştırma Projeleri Birimi tarafından FYL-2017784 proje numarası ile Yüksek Lisans Tezi Araştırması olarak desteklenmiştir. Projemize destek veren RTEÜ Bilimsel Araştırma Projeleri Birimi ve LAZUTİM Gıda, Tarım ve Hayvancılık şirketine teşekkür ederiz.

\section{KAYNAKLAR}

AOAC (Association of Official Analytical Chemists), (2000). Official methods of analysis, 19th edn. AOAC, Arlington, Virginia, USA.

Arıman Karabulut, H., Kurtoğlu, I., Yüksek, T. \& Osmanoğlu, M.í. (2016). Balık Yemlerinde Hayvansal Protein Kaynağı Olarak Solucan Ununun Kullanımı, Anadolu Çevre ve Hayvancılık Bilimleri Dergisi, 1(2), 64-69.

Atiyeh, R.M., Edwards, C.A, Subler, S. \& Metzger, J.D. (2000). Earthworm processed organic wastes as components of horticultural potting media for growing marigolds and vegetable seedlings. Compost Science and Utilization, 8, 215- 233.

Baier-Anderson, C. \& Anderson, R.S. (2000). The effects of Chlorothalonil on oyster hemocyte activation: Phagocytosis, reduced pyridine nucleotides, and reactive oxygen species production. Environmental Research, 83(1), 72-78.

Beard, J. (2006). DDT and human health. Science of the Total Environment, 355(1), 78-89.

Bellitürk, K., Görres, J.H., Turan, H.S., Göçmez, S., Bağdatlı, M.C., Eker, M. \& Aslan, S. (2014). Zeytin Bitki Artıkları-Ahır Gübresi-Kum Karışımı ile Yapılacak Olan Vermikompostun Tarımda Kullanılabilirliğinin Araştırılması. Namık Kemal Üniversitesi Bilimsel Araştırma Projesi, Proje No: NKUBAP.00.24.AR.13.15.

Boehm, M.J., Madden, L.V. \& Hoitink, H.A.J. (1993). Effect of organic matter decomposition level on bacterial species diversity and composition in relationship to Pythium damping -off severity. Applied and Environmental Microbiology, 59, 41714179.

Buchanan, M.A, Russell, E. \& Block, S.D. (1988). Chemical characterization and nitrogen earthworms in environmental and waste management In C.A.Edwards and E.F. Neuhauser (Eds.), SPB Acad. Publ., The Netherlands, 231-240.
Chen, S.K., Edwards, C.A. \& Subtler, S. (2001). Effects of the fungicides benaomyl, captan and chlorothalonil on soil microbial activity and nitrogen dynamics in laboratory incubations. Soil Biology and Biochemistry, 33(14), 1971-1980.

Chen, Y. \& Aviad, T. (1990). Effects of humic substances on plant growth. In: MacCarthy, P., C.E. Clapp, R.L. Malcolm and P.R. Bloom (eds) Humic Substances in Soil and Crop Sciences: Selected Readings. ASA and SSSA, Madison, Wisconsin, USA, 161-186.

Das, D., Bhattacharyya, P., Ghosh, B.C. \& Banik, P. (2016). Bioconversion and biodynamics of Eisenia foetida in different organic wastes through microbially enriched vermiconversion technologies. Ecological Engineering, 86, 154-161.

Dominguez, J., Edwards, C.A. \& Subler, S. (1997). A comparison of vermicomposting and composting. Biocycle, 38, 57-59.

Edwards, C.A., \& Bohlen, P.J. (1996). Biology and Ecology of Earthworms. 3rd. edition, ISBN: 978-0412-56160-3, 438 pp.,196-212.

Erşahin, Y.Ş. (2007b). Vermikompost ürünlerinin eldesi ve tarımsal üretimde kullanım alternatifleri. Gaziosmanpaşa Üniversitesi Ziraat Fakültesi Dergisi, 24(2), 99-107.

Garg, P., Gupta, A. \& Satya, S. (2006). Vermicomposting of different types of waste using Eisenia foetida: A comparative study. Bioresource technology, 97(3), 391-395.

Gündüzalp, A.A. \& Güven, S., 2016. Atık, çeşitleri, atık yönetimi, geri dönüşüm ve tüketici: Çankaya Belediyesi ve semt tüketicileri örneği. Hacettepe Üniversitesi Sosyolojik Araştırmalar E-Dergisi, ISSN, 1304-2823.

Huang, G.F., Wong, J.W., Wu, Q.T. \& Nagar, B.B. (2004). Effect of $\mathrm{C} / \mathrm{N}$ on composting of pig manure with sawdust. Waste Management, 24(8), 805-813.

İlay, R., Kavdır, Y. \& Sümer, A. (2013). The effect of olive oil solid waste application on soil properties and growth of sunflower (Helianthus annuus L.) and bean (Phaseolus vulgaris L.). International Biodeterioration \& Biodegradation, 85, 254-259.

Joshi, R. \& Pal Vig, A. (2010). Effect of vermicompost on growth, yield and quality of tomato (Lycopersicum esculentum L). African Journal of Basic \& Applied Sciences, 2(3), 117-123.

Kale, R.D., Mallesh, B.C., Kubra, B. \& Bagyaraj, D.J. (1992). Influence of vermicompost application on the available macronutrients and selected microbial populations in a paddy field. Soil Biology and Biochemistry, 24, 1317-1320.

Karaçal, İ. \& Tüfenkçi, Ş. (2010). Bitki Beslemede Yeni Yaklaşımlar ve Gübre-Çevre İlişkisi, Ziraat Mühendisliği VII. Teknik Kongresi, 257-268. 
Lange, M.G. (2005). A Comparison Analysis of Vermicomposting Strategies in Food Substrates with an Emphasis on Nutrient Values and Reproduction. Pioneer Undergraduate Research Fellowship, 1-15.

Manyuchi, M.M. \& Phiri, A. (2013). Vermicomposting in solid waste management: a review. International Journal of Scientific Engineering and Technology, 2(12), 1234-1242.

Masciandro, G., Ceccanti, B. \& Garcia, C. (1997). Soil agro-ecological management: fertirrigation and vermicompost treatments. Bioresource Technology, 59, 199-206.

Neuhauser, E.F, Loehr, R.C. \& Malecki, M.R. (1988). The Potential of Earthworms for Managing Sewage Sludge. Earthworms and Waste Management. SPB Academic Publishing, ISBN: 90-5103-017-7, Edwards, C.A., Neuhauser, E.F. (Eds.), 9-20.

Orlov, D.S. \& Biryukova, O.N. (1996). Humic substances of vermicomposts. Agrokhimiya, 12, 60-67.

Orozco, S. H., Cegarra, J., Trujillo, L. M. \& Roig, A. (1996). Vermicompostsing of coffee pulp using the earthworm Eisenia fetida: effects on $\mathrm{C}$ and $\mathrm{N}$ contents and the availability of nutrients. Biology and Fertility of Soils, 22, 162-171.

Parthasarathi, K. (2007). Life cycle of Lampito mauritii (Kinberg) in comparison with Eudrilus eugeniae (Kinberg) cultured on different substrates. Journal of Environmental Biology, 28(4), 80-812.

Punde, B.D. \& Ganorkar, R.A. (2012). Vermicompostingrecycling waste into valuable organic fertilizer. International Journal of Engineering Research and Applications, 2, 2342-2347.

Shanmugasundaram, R., Jeyalakshmi, T., Saravanan, M., Mohan, S.S., Goparaju, A. \& Murthy, P.B. (2013). Influence of some biological wastes and their combination on growth and reproduction potential of earthworm, Eisenia fetida and their effect on plant growth. International Journal of Environment and Waste Management, 11(4), 387398.

Sherman, R. (2003). Raising earthworms successfully.North Carolina Cooperative Extension Service Publication Number: EBAE 103-83 Last Electronic Revision:

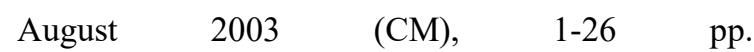
https:/www.bae.ncsu.edu/extension/extpublications/ waste/composting/agw-641_rasing-earthworms.pdf,
Suthar, S., Kumar, K. \& Mutiyar, P.K. (2014). Nutrient recovery from compostable fractions of municipal solid wastes using vermitechnology. Journal of Material Cycles and Waste Management, 17(1), 174-184.

Suthar, S., Pandey, B., Gusain, R. and Gaur, R.Z., 2016. Nutrient changes and biodynamics of Eisenia fetida during vermicomposting of water lettuce (Pistia sp.) biomass: a noxious weed of aquatic system. Environmental Science and Pollution Research, 24(1), 199-207.

URL-1，2007. http://www.zmo.org.tr/etkinlikler/6tk05/016 uygunaksoy. pdf (11 Aralik 2007).

Wang, L., Zhang, Y., Lian, J., Chao, J., Gao, Y., Yang, F. \& Zhang, L. (2013). Impact of fly ash and phosphatic rock on metal stabilization and bioavailability during sewage sludge vermicomposting. Bioresource Technology, 136, 281-287.

Yüksek, T. (2016). Farklı tip yemle beslenen kırmızı Kalifornia solucanı (Eisenia fetida)'nın biomass (Solucan sayısı ve toplam ağırlı̆̆ı) verimi ve meydana gelen gübrenin bazı kalite parametrelerine etkisinin araştırılması. Sanayi İşbirliği Projesi. Recep Tayyip Erdoğan Üniversitesi, Rize, Türkiye, Proje No: 253.

Yüksek, T., Verep, B. \& Baltacı, C. (2017). Hayvan gübresinden elde edilen sıv1 solucan gübresinin iz ve besin elementleri açısından incelenmesi. Turkish Journal of Agriculture: Food Science and Technology, 5(8), 986-991.

Yüksek, T. (2019). Farklı tip yemle beslemenin kırmızı Kaliforniya solucanında solucan sayısı ve ağırlığına etkisinin belirlenmesi. Anadolu Çev. ve Hay. Dergisi, 4(1), 1-6.

\section{*Corresponding author's:}

Prof. Dr. Turan YÜKSEK

Recep Tayyip Erdoğan Üniversitesi, Peyzaj Mimarlı̆̆ı, Bölümü, Fener Yerleşkesi, 53100/ Rize, Türkiye.

\E-mail: turan.yuksek@erdogan.edu.tr

ORCID: https://orcid.org/0000-0003-2964-1760 